\title{
Opening or Solidifying? The Trend of the Intergenerational Mobility in China since the Implementation of the Reform and Opening-up Policy
}

\author{
Zhiqiang Yue, ${ }^{1}$ Ke Yin ${ }^{2}$ \\ 1. Jiangxi Normal University, Nanchang, Jiangxi, China \\ 2. Jiangxi University of Science and Technology, Nanchang, Jiangxi, China
}

\begin{abstract}
Based on the findings of the China General Social Survey, this study aims to analyze the trend of the intergenerational mobility in China since the implementation of the reform and opening-up policy by evaluating the absolute and relative mobility rates through the mobility table. The intergenerational mobility level in China is relatively high from the perspective of the absolute mobility rates. Besides, the overall trend is upward and social openness is quite high. However, the intergenerational mobility level is relatively low and gradually declining from the perspective of the relative mobility rates that reflect the equality of mobility opportunities. In addition, the social class structure shows a tendency of solidifying. While the absolute mobility rates reflect the efficiency of the intergenerational mobility, the relative mobility rates reflect its fairness. However, since the implementation of the reform and opening-up policy, Chinese society appears to be in a state of inadequate equality but with high efficiency. In this study, we generally regarded education as a critical factor of the intergenerational mobility. Lately, China has implemented a series of education policies, including the resumption of university entrance examination policy, compulsory education policy, and college enrollment expansion policy. The Chinese government endeavors to enhance national education attainment and sustain absolute mobility at a higher level. Nevertheless, the differences in education attainment of offspring from different social classes have increased gradually, making education inequality a significant factor of lower relative mobil-
\end{abstract}


Yue \& Yin. Intergenerational Mobility in China after the Reform and Opening-up.

ity. Thus, the government should increase the intergenerational mobility level by creating a healthy and stable economic development environment and improving education inequality.

Sci Insigt Edu Front 2020; 6(1):579-598.

Doi: 10.15354/sief.20.or015

How to Cite: Yue, Z., Yin, K. (2020) Opening or solidifying? The trend of the intergenerational mobility in China since the implementation of the reform and opening-up policy. Sci Insigt Edu Front, 6(1):579-598.

Keywords: Social Class; Solidifying; Intergenerational Mobility; Education Inequality; Reform and Opening-up Policy

About the Author: Ke Yin, Lecturer, Core Curriculum Department, Jiangxi University of Science and Technology, Nanchang 330013, Jiangxi Province, China. Email: 304965208@qq.com

Correspondence to: Zhiqiang Yue, Lecturer, Institute of Education, Jiangxi Normal University, Nanchang 330022, Jiangxi Province, China. Email: zhiqiangyue@sina.com.

Funding: Key Project of Philosophy and Social Science Research of the Ministry of Education of China "Study on the Relationship between Education and Economic Development and the Contribution of Education" (Project No.: 15JZD040, to Yuhong Du)

Conflict of Interests: None. 


\section{Introduction}

7 HE intergenerational mobility denotes the extent and pattern of the relationship between parents' and adult children's socioeconomic status (Torche, 2015).

Typically, socioeconomic status is captured by social class, where a higher correlation between parents' and offspring's social class implies lower intergenerational mobility. Alternatively, the social class structure is more profound and the social openness is lower. Scholars mainly believe that the intergenerational mobility level denotes the extent of inequality of opportunities, which primarily ascertains the inequality of results. The lower the intergenerational mobility level, the more serious social inequality is (Becker \& Tomes, 1979).

Since 1978, Chinese society has witnessed revolutionary changes when the Chinese government began implementing the reform and opening-up policy. However, criticism on the low intergenerational mobility level or the solidification of the social class structure is emerging, with keywords like "the second rich generation," "the second official generation," and "the second poor generation" frequently appearing in the media. The existing literature concurs that education is a crucial factor in achieving individual social status attainment. Since the implementation of the reform and openingup policy, changes in China's education sector have garnered worldwide attention. A series of prominent education policies, such as the policy of resuming the college entrance examination, compulsory education, and college enrollment expansion, have markedly enhanced the education level of Chinese citizens, thereby providing Chinese people with more opportunities of intergenerational upward mobility. However, the rising tuition fees in colleges and universities, as well as challenges of job hunting for college students, has paved the way for the opinion of uselessness of education. Consequently, many people, including scholars, are pessimistic about the intergenerational mobility of Chinese society; they believe that children of disadvantaged groups can hardly increase their social status by only through education.

The phenomena mentioned above raises the following questions: what is the intergenerational mobility level in China? What factors affect the intergenerational mobility? What role does education play in the intergenerational mobility? Hence, this study aims to use the China General Social Survey (CGSS) data as a basis to empirically investigate the level and trend of the intergenerational mobility in China, address the practical question of whether the social class structure is solidifying, and examine the reasons for the intergenerational mobility, especially educational factors. Perhaps, this study can provide empirical evidence to the government to improve social inequality.

\section{Literature Review}

First, if empirical methods are used to investigate the intergenerational mobility level in China, we must understand the measurement methods of the intergenerational mobility level. Sociologists have primarily used methods such as mobility tables, log-linear 
models, and log-multiplicative layer effect models, whereas economists have preferred intergenerational income elasticity. In the mid-1950s, scholars like Glass and Berent (1954) and Handlin, Lipset, and Bendix (1959) proposed mobility table, which is one of the most fundamental analysis tools for the intergenerational mobility research and belongs to the descriptive statistical method. Based on the mobility tables, the indexes of the intergenerational mobility rates and the intergenerational mobility distance can be calculated. In the mid-1970s, some researchers used log-linear models or logmultiplicative layer effect models based on the mobility tables (Erikson \& Goldthorpe, 1992; Xie, 1992). However, the tendency to pursue sophisticated statistical techniques has limited the intergenerational mobility research to the exploration of the correlation between the social status of parents and offspring, ignoring the general interest of the intergenerational mobility research such as the determinants and consequences of the intergenerational mobility (Treiman \& Ganzeboom, 2000). The intergenerational income elasticity proposed by economists focuses on the correlation between the permanent income of parents and their offspring; this can be used to assess the intergenerational mobility level and elucidate the mechanism of the intergenerational mobility to some extent. However, the intergenerational income mobility often experiences lifecycle bias and measurement errors. Thus, considering the estimation bias of the intergenerational income elasticity, using sociologists' method to measure the intergenerational mobility level seems more appropriate. Although log-linear models or logmultiplicative layer effect models can more precisely measure the intergenerational mobility level, the mobility rates based on the mobility tables remain crucial means for several scholars to study the intergenerational mobility level.

The trend of the intergenerational mobility has always been a hot topic in the research of the intergenerational mobility. The existing literature usually believes that since the implementation of the reform and opening-up policy, although the social class structure of Chinese society is continually evolving, it has become increasingly "hierarchical." From the viewpoint of occupational status mobility and social class mobility, the existing research can be roughly categorized into two groups: (a) one group believes that industrialization and urbanization provide opportunities for social members to be upward, and the social class structure is opening (Lu, 2004); (b) one group believes that the class reproduction is in a dominant position and the social class structure is increasingly solidifying or even broken (Li, 2002; Li, 2011; Sun, 2003). For now, the latter point dominates the discussion. From the standpoint of income mobility, the existing literature rarely involves the analysis of the intergenerational mobility trend in China. Moreover, research conclusions vary considerably because of different sample selection and estimation methods. Furthermore, some studies indicated that the intergenerational mobility level has gradually increased from a rapid level to gradually stabilized level (Chen \& Yuan, 2012); while some considered a general downward trend ( $\mathrm{Li} \&$ Zhou, 2014), others considered an overall upward trend (Yang \& Zhang, 2015).

Overall, the existing research notably deviates on the trend of the intergenerational mobility in China since the implementation of the reform and opening-up policy. Besides the analysis tools and data resources, it is primarily because several studies did 
not realize the difference between absolute mobility rates and relative mobility rates when evaluating the mobility rates. The absolute mobility rates are basic indicators to assess the intergenerational mobility, which can observe the fundamental situation of the intergenerational mobility in the entire society. During rapid economic and educational development, everyone tends be more outstanding than their parents in theory such as higher education level, higher income, and higher occupational status. The higher absolute mobility rates depict intergenerational progress in this sense. The relative mobility rates illustrate the opportunity equality of the social class mobility and can more precisely reflect the social openness, which implies that the absolute and relative mobility rates are not necessarily synchronized. Thus, it is essential to comprehensively discuss the level and trend of the intergenerational mobility of Chinese society from the two indicators, respectively.

\section{Data}

The research data were obtained from the CGSS database released by the National Survey Research Center at the Renmin University of China. The CGSS used the multistratified, multistage PPS (probability proportionable to size sampling) random sampling method to collect data at multiple levels of society, communities, families, and individuals systematically and comprehensively. The survey from 2010 to 2019 was the second phase of the sample survey, with a sampling target of 31 provincial administrative units nationwide (excluding Hong Kong, Macao, and Taiwan). To date, data from 2010 to 2013 and 2015 have been publicly released. The analysis database contains the age of respondents and the occupation information of parents and offspring. Owing to various missing values of the occupation variables in the database, to expand the sample size, we merged the data of 2013 and 2015 to form mixed cross-sectional data. The labors that entered the labor market after the implementation of the reform and openingup policy were primarily born after 1960; thus, those who were born between 1960 and 1999 were selected in this study. After data cleaning, the sample size of the analysis database was 7654 .

\section{Methods}

Both absolute and relative mobility rates can be calculated on the basis of mobility tables, thereby enabling the analysis of the intergenerational mobility level. The social positions of parents and offspring are often measured by "social class," whereas the EGP class classification is a commonly used social class classification method proposed by Erikson, Goldthorpe and Portocarero (Erikson \& Goldthorpe, 1992). Thus, considering the 11-class EGP social class classification and the related research (Ganzeboom, Luijkx \& Treiman, 1989), we can classify the EGP social classes into six categories based on the occupational information. Referring the Goldthorpe's work experience mobility model (Li, 2008), the six social classes can be further clustered into three major classes as follows: (a) professionals, administrators, and managers: regarded as the upper social class; (b) routine nonmanual employees and small proprietors: regarded as 
the middle social class; (c) skilled workers, unskilled workers, and agricultural workers: regarded as the lower social class. Table 1 shows the final classification of the social classes.

Based on the mobility tables, we can calculate the mobility rate indexes reflecting the intergenerational mobility level. The mobility rates primarily include the absolute and relative mobility rates.

The absolute mobility rates primarily include inflow rates, outflow rates, hereditary rates, upward mobility rates, downward mobility rates, and total mobility rates. The inflow and outflow rates reflect the mobility state of each social class, including horizontal and vertical mobility. The inflow rate of a certain social class can denote the source of the parental social class, that is, the ratio of the frequency of a certain cell to the marginal distribution of the column. Conversely, the outflow rate of a certain social class can denote the flow direction of the offspring, that is, the ratio of the frequency of a certain cell to the marginal distribution of the row.

The hereditary rates, upward mobility rates, and downward mobility rates can reflect the mobility state of a certain social class, as well as that of the whole society. The hereditary rates signify horizontal mobility, whereas the upward and downward mobility rates reflect vertical mobility. The hereditary rate of a certain social class suggests that the status of the offspring's social class did not change relative to the status of the parental social class. In other words, it is the ratio of a certain frequency on the diagonal in the mobility table to the marginal distribution of the row. In this case, the hereditary rate is the special case of the outflow rate. Of course, the hereditary rates can also indicate that no change occurs in the status of the offspring's social class relative to the parental social class in the whole society. The hereditary rates can be evaluated by the ratio of the sum of frequencies on the diagonal of the mobility table to the sample size. The upward mobility rate of a certain social class indicates the upward probability of the offspring's social class relative to the parental social class, whereas the downward mobility rate indicates the downward probability of the offspring's social class relative to the parental social class. For a certain social class, the sum of the hereditary rate, upward mobility rate, and downward mobility rate is equal to 1 . For the entire society, the upward mobility rate denotes the ratio of social members flowing to higher social classes in the vertical social mobility; it is the sum of the frequencies of the cells below the diagonal of the mobility table divided by the sample size. The downward mobility rate denotes the ratio of social members flowing to lower social classes in the vertical social mobility; it is the sum of the frequencies of the cells above the diagonal in the mobility table divided by the sample size.

The total mobility rate implies the overall state of the vertical mobility of the whole society. As the hereditary rate is the opposite of the total mobility rate, the total mobility rate equals 1 minus the hereditary rate. The total mobility rate denotes the intergenerational mobility level in the whole society; the higher the value, the higher the intergenerational mobility level. For the whole society, the sum of the upward and downward mobility rates is the total mobility rate. 


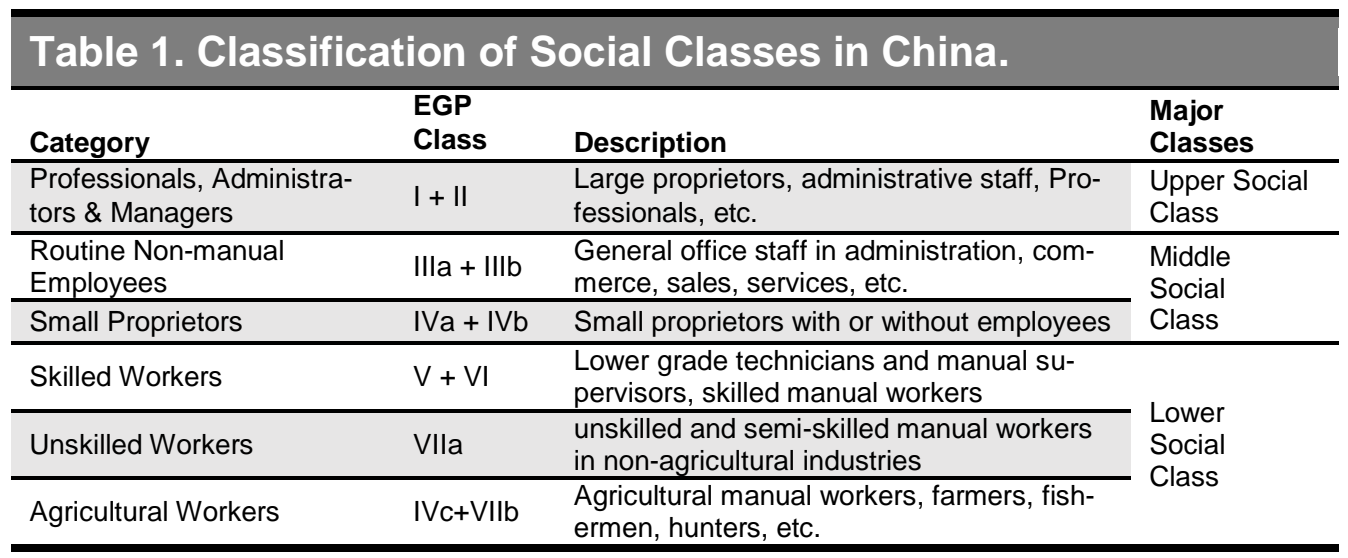

The relative mobility rates primarily include intergenerational inheritance indexes, intergenerational inflow indexes, intergenerational outflow indexes, intergenerational upward mobility indexes, and intergenerational downward mobility indexes. The calculation of the relative mobility rates depends on the mobility ratio indexes. The relative mobility rates can be evaluated by establishing the table of mobility ratios, which is a two-dimensional contingency table of the mobility ratios between social classes of parents and offspring. The mobility ratio of a certain social class is evaluated by the ratio of the actual frequency of a certain cell in the table of mobility ratios to the expected frequency. If the mobility ratio is 1 , it implies that the offspring from any social class are completely randomly distributed in a certain social class. If the mobility ratio is $>1$ or $<1$, it implies that the probability of offspring from other social classes flowing a certain social class is higher than or less than the probability of the offspring inheriting the certain social class.

The intergenerational inheritance index denotes the intergenerational inheritance level of a certain social class; the higher the value, the more notable the intergenerational inheritance effect of the social class is and the lower the level of intergenerational mobility is. Numerically, the intergenerational inheritance index is the values on the diagonal of the mobility ratio table.

The intergenerational inflow and outflow indexes measure the possibility of vertical mobility of a certain social class from the perspective of equal opportunity. The intergenerational inflow index denotes the possibility of children from other social classes flowing into a certain social class; the larger the index, the more likely the offspring from other social classes are to enter the certain social class, the higher the intergenerational mobility level is, and the lower the intergenerational inheritance effect is. On the other hand, the intergenerational outflow index denotes the possibility of the offspring outflows from the parental social class to another social class; the larger the index, the more likely the offspring from a certain social class are to enter other social classes, the higher the intergenerational mobility level is, and the lower the intergenerational inher- 
itance effect is. The calculation formulas of the intergenerational inflow and outflow indexes are shown in formula (1):

$$
\mathrm{VR}_{j}=\frac{\sum_{\mathrm{i} \neq \mathrm{j}} \mathrm{b}_{\mathrm{ij}}}{n-1}
$$

where $b_{i j}$ denotes the mobility ratio, $i$ is the parental social class, and $j$ is the offspring's social class. In other words, it is the value of a certain cell in the table of mobility ratio. Then, $n$ is the total number of social class. The intergenerational inflow index denotes the possibility that parents are not from the social class $j$, while the offspring inflows to the social class $j$. The intergenerational outflow index denotes the likelihood that parents are from the social class $i$, whereas the offspring outflows from the social class $i$ to another social class.

The intergenerational downward and upward mobility indexes can measure the direction of the vertical mobility of the whole society from the perspective of equality opportunities. Equations (2) and (3) present the calculation formulas of the intergenerational downward and upward mobility indexes, respectively:

$$
\begin{aligned}
& U_{\mathrm{j}}= \frac{\sum_{\mathrm{j}<i} \mathrm{~b}_{\mathrm{ij}}}{\frac{\mathrm{n}(\mathrm{n}-1)}{2}} \\
& \mathrm{DR}_{\mathrm{j}}=\frac{\sum_{\mathrm{i}<j} \mathrm{~b}_{\mathrm{ij}}}{\frac{\mathrm{n}(\mathrm{n}-1)}{2}}
\end{aligned}
$$

where $b_{i j}$ denotes the mobility ratio, $i$ is the parental social class, $j$ is the offspring's social class, and $\mathrm{n}$ is the total number of social class.

Notably, when calculating the mobility rates, we adopted the "superiority" method to measure the parental social class. We compared the social class status of the father and mother, and adopted the higher as the value of "the parental social class." Compared with the method of only using the value of the father's social class, the "superiority method" can depict the family influence on the class status of offspring comprehensively.

\section{The Trend of the Intergenerational Mobility and its Reasons}

The trend of the intergenerational mobility in China can be illustrated by evaluating the intergenerational mobility level of different birth generations entering the labor market 
after the implementation of the reform and opening-up policy. Based on the birth year, respondents who entered the labor market after 1978 were roughly categorized into four birth generations as follows: (a) post-1960s generation (birth year: 1960-1969); (b) post-1970s generation (birth years: 1970-1979); (c) post-1980s generation (birth year: 1980-1989); and (d) post-1990s generation (birth year: 1990-1999).

The four generations mentioned above have experienced social changes in different periods of China's reform and opening-up policy, and their education and employment have different characteristics, which determine their social class status to a large extent. The post-1960s generation primarily received education during the "cultural revolution" and before the reform of the market economy system. The education of the post-1960s generation was markedly influenced by the "cultural revolution" and the planned economy system. The post-1960s generation mostly entered the labor market at the beginning of the reform and opening-up policy, and their employment was significantly affected by the social environment. The post-1970s generation chiefly received education after the "cultural revolution," or after the implementation of the reform and opening-up policy; they began entering the labor market at the beginning of the reform and opening-up policy or the preliminary stage of the market economy system reform. Although their education and employment are influenced by the planned economy system comprehensively, a rather large number of people were also affected by the transition from the planned economy system to the market economy system. The post-1980s generation began receiving education during the deepening of reform and opening-up policy or the early stage of the market economy system reform; their education process was in the stage of legalization of compulsory education and college enrollment expansion in China. The entire post-1980s generation began entering the labor market in the process of the gradual improvement of the market economy system, and their employment was considerably affected by the market economy system. Finally, the post-1990s generation began receiving education after the establishment of the market economy system; their education process is in the stage of free compulsory education and higher education popularization in China. Furthermore, the employment of the post-1990s generation is affected by slowing growth of economy in China.

\section{The Absolute Mobility Rates}

Based on the mobility table, we can calculate the hereditary rates, upward mobility rates, and downward mobility rates of each social class. Owing to limited space, the mobility table is not presented in this study. As is shown in Table 2, generally, the proportion of offspring who inherit parental social class is not high. The highest hereditary rate is in the class of agricultural workers $(42.8 \%)$, whereas the lowest is in the class of skilled workers $(13.4 \%)$. From the viewpoint of upward mobility rates, the probability of upward mobility in the lower social classes, such as skilled workers, unskilled workers, and agricultural workers, is significantly higher than the probability of upward mobility in the middle social classes, including routine nonmanual employees and small proprietors. From the perspective of downward mobility rates, professionals, administrators, 


\begin{tabular}{|c|c|c|c|}
\hline \multicolumn{4}{|c|}{$\begin{array}{l}\text { Table 2. The Hereditary Rates, Upward Mobility Rates and } \\
\text { Downward Mobility Rates of All Social Classes in China sinc } \\
\text { the Implementation of the Reform and Opening-Up Policy ( } \%\end{array}$} \\
\hline Social Class & $\begin{array}{l}\text { Hereditary } \\
\text { Rate }\end{array}$ & $\begin{array}{l}\text { Upward } \\
\text { Mobility Rate }\end{array}$ & $\begin{array}{l}\text { Downward } \\
\text { Mobility Rate }\end{array}$ \\
\hline Professionals, Administrators \& Managers & 37.7 & 0 & 62.3 \\
\hline Routine Non-manual Employees & 14.1 & 28.2 & 57.7 \\
\hline Small Proprietors & 36.1 & 30.0 & 33.9 \\
\hline Skilled Workers & 13.4 & 56.8 & 29.7 \\
\hline Unskilled Workers & 22.7 & 63.6 & 13.7 \\
\hline Agricultural Workers & 42.8 & 57.2 & 0 \\
\hline
\end{tabular}

\begin{tabular}{|c|c|c|c|c|c|}
\hline & $\begin{array}{l}\text { Whole } \\
\text { Nation }\end{array}$ & $\begin{array}{l}\text { The Post-1960s } \\
\text { Generation }\end{array}$ & $\begin{array}{l}\text { The Post-1970s } \\
\text { Generation }\end{array}$ & $\begin{array}{l}\text { The Post-1980s } \\
\text { Generation }\end{array}$ & $\begin{array}{l}\text { The Post-1990s } \\
\text { Generation }\end{array}$ \\
\hline $\begin{array}{l}\text { Total } \\
\text { Mobility Rate }\end{array}$ & 61.77 & 51.58 & 64.21 & 70.60 & 67.67 \\
\hline $\begin{array}{l}\text { Upward } \\
\text { Mobility Rate }\end{array}$ & 46.73 & 36.90 & 48.55 & 55.69 & 53.57 \\
\hline $\begin{array}{l}\text { Downward } \\
\text { Mobility Rate }\end{array}$ & 15.04 & 14.67 & 15.66 & 14.91 & 14.10 \\
\hline
\end{tabular}

and managers, routine non-manual employees who are in the upper or middle position of the social class structure have a higher risk of downward mobility. From the standpoint of the comparison of upward and downward mobility rates, for professionals, administrators, and managers, routine nonmanual employees and small proprietors who are in the upper or middle position of the social class structure, the upward mobility rates are usually lower than the downward mobility rates. For skilled workers, unskilled workers, and agricultural workers who are in the lower position of the social class structure, the upward mobility rates are usually higher than downward mobility rates. Hence, the level of mobility among different social classes is satisfactory in China.

Through the mobility table, the absolute mobility rates, such as total mobility rates, upward mobility rates, and downward mobility rates, of the whole society can be evaluated; they can reflect the overall level of the intergenerational mobility in the whole society (Table 3). Based on the overall national value, the total mobility rate of Chinese society is quite high, and the flow direction is primarily upward, and the upward mobility rate is markedly higher than the downward mobility rate. From the perspective of the value of four birth generations, the total mobility rates of Chinese socie- 
ty exhibit a continuous rising trend; however, it has declined marginally in recent years. However, the direction of the intergenerational mobility was always upward. The conclusions presented above are basically consistent with Gu (2016), who held that the level of the absolute mobility rates in Chinese society has been increasing continuously and the intergenerational mobility was primarily upward.

\section{The Relative Mobility Rates}

First, we analyzed the overall level of the intergenerational mobility of Chinese society since the implementation of the reform and opening-up policy from the perspective of relative mobility rates.

As shown in Table 4, the mobility ratios on the diagonal of the table, namely the intergenerational inheritance indexes, are significantly $>1$ (mean value: 2.18 ). The intergenerational inheritance index of routine nonmanual employees and professionals, administrators, and managers are notably larger. Except the intergenerational inheritance indexes, the mean value of the other 30 intergenerational mobility ratios was 1.01 , and approximately 13 intergenerational mobility ratios were $<1$. The mean value of intergenerational outflow and inflow indexes was 1.01 and 1.05, respectively, demonstrating that the offspring probably inherit their parental social class, but children from various social classes still have some opportunities to change their original social class status. Generally, the intergenerational mobility level in China is relatively low; however, society remains open to some extent.

Regarding the intergenerational outflow index of a specific social class, the intergenerational outflow index of all social classes is around 1, except for agricultural workers, suggesting that the offspring from most social classes have equal opportunities to change their original social class. In addition, the intergenerational outflow index of professionals, administrators, and managers is close to 1 ; however, the offspring of professionals, administrators, and managers tend to flow to social classes of middle social status, including routine nonmanual employees and small proprietors. The likelihood of upward mobility of the offspring from routine nonmanual employees and small proprietors is higher than the likelihood of downward mobility. Moreover, the possibility of upward mobility of the offspring from skilled and unskilled workers is higher than the possibility of downward mobility; however, they mainly flow to social classes of middle social status, that is, routine nonmanual employees and small proprietors. The intergenerational outflow index of agricultural workers is the lowest, who not only have relatively few upward mobility opportunities but also mostly flow to social classes of low social status, namely skilled and unskilled workers. Hence, the findings suggest that the intergenerational mobility of Chinese society is more inclined to be short-distance mobility, which corroborates Guo (2009) and Gu (2016).

Regarding the intergenerational inflow index of a specific social class, except for skilled workers and agricultural workers, the intergenerational inflow indexes of all other social classes are $>1$, suggesting that most social classes tend to absorb the offspring of other social classes. The intergenerational inflow indexes of professionals, 


\begin{tabular}{|c|c|c|c|c|c|c|c|}
\hline Offspring & $\begin{array}{l}\text { Profession- } \\
\text { als, Adminis- } \\
\text { trators \& } \\
\text { Managers } \\
\end{array}$ & $\begin{array}{l}\text { Routine } \\
\text { Non- } \\
\text { Manual } \\
\text { Employ- } \\
\text { ees }\end{array}$ & $\begin{array}{l}\text { Small } \\
\text { Proprie- } \\
\text { tors }\end{array}$ & $\begin{array}{l}\text { Skilled } \\
\text { Work- } \\
\text { ers }\end{array}$ & $\begin{array}{l}\text { Un- } \\
\text { skilled } \\
\text { Work- } \\
\text { ers }\end{array}$ & $\begin{array}{l}\text { Agricul- } \\
\text { tural } \\
\text { Workers }\end{array}$ & $\begin{array}{l}\text { Intergenera- } \\
\text { tional Outflow } \\
\text { Indexes }\end{array}$ \\
\hline $\begin{array}{l}\text { Professionals, } \\
\text { Administrators } \\
\& \text { Managers }\end{array}$ & 2.28 & 2.05 & 1.08 & 0.65 & 0.69 & 0.41 & 0.98 \\
\hline $\begin{array}{l}\text { Routine } \\
\text { Non-manual } \\
\text { Employees }\end{array}$ & 1.7 & 4.92 & 1.16 & 0.5 & 1.39 & 0.09 & 0.97 \\
\hline $\begin{array}{l}\text { Small } \\
\text { Proprietors } \\
\end{array}$ & 1.52 & 1.68 & 1.42 & 0.88 & 0.91 & 0.4 & 1.08 \\
\hline $\begin{array}{l}\text { Skilled } \\
\text { Workers }\end{array}$ & 1.2 & 1.54 & 1.28 & 1.57 & 1.42 & 0.26 & 1.14 \\
\hline $\begin{array}{l}\text { Unskilled } \\
\text { Workers }\end{array}$ & 1.15 & 1.41 & 1.16 & 1.3 & 1.5 & 0.44 & 1.09 \\
\hline $\begin{array}{l}\text { Agricultural } \\
\text { Workers }\end{array}$ & 0.59 & 0.51 & 0.88 & 1.02 & 0.99 & 1.36 & 0.8 \\
\hline $\begin{array}{l}\text { Intergenera- } \\
\text { tional Inflow } \\
\text { Indexes }\end{array}$ & 1.39 & 1.44 & 1.11 & 0.87 & 1.16 & 0.32 & - \\
\hline
\end{tabular}

\begin{tabular}{|c|c|c|c|c|c|}
\hline & $\begin{array}{l}\text { The } \\
\text { Whole } \\
\text { Nation }\end{array}$ & $\begin{array}{l}\text { Post-1960s } \\
\text { Generation }\end{array}$ & $\begin{array}{l}\text { Post-1970s } \\
\text { Generation }\end{array}$ & $\begin{array}{l}\text { Post-1980s } \\
\text { Generation }\end{array}$ & $\begin{array}{l}\text { Post-1990s } \\
\text { Generation }\end{array}$ \\
\hline $\begin{array}{l}\text { The Intergenerational } \\
\text { Upward Mobility In- } \\
\text { dexes }\end{array}$ & 1.2 & 1.39 & 1.15 & 1.07 & 1.04 \\
\hline $\begin{array}{l}\text { The Intergenerational } \\
\text { Downward Mobility } \\
\text { Indexes }\end{array}$ & 0.85 & 1.16 & 0.84 & 0.75 & 0.6 \\
\hline
\end{tabular}

administrators, and managers and routine nonmanual employees are at the top of all indexes and > 1, which signifies that the offspring of other social classes have more opportunities to flow to the two classes. Nevertheless, the offspring of routine nonmanual employees and small proprietors have relatively more opportunities to enter the two classes than the offspring from social classes with lower social status. The intergenerational inflow index of small proprietors is in the middle of all indexes. The offspring of other social classes tend to flow to the class of small proprietors, except for agricultural workers. The intergenerational inflow index of skilled workers is lower, and the offspring of other classes tend to enter this class; however, the offspring of unskilled 
workers and agricultural workers with lower social status tend to enter this class. The intergenerational inflow index of unskilled workers is also higher, but the offspring of skilled workers and routine nonmanual employees tend to enter this class. Moreover, the intergenerational mobility ratio of agricultural workers is 1.36 , and the intergenerational inflow index of this class is significantly $<1$, demonstrating that agricultural workers are not only more likely to inherit the social class from their parents but also not inclined to absorb offspring from other social classes. Thus, the class of agricultural workers is highly closed.

Next, the trend of the relative mobility rates of Chinese society since the implementation of the reform and opening-up policy can be assessed by evaluating the relative mobility rates of the four birth generations - post-1960s generation, post-1970s generation, post-1980s generation, and post-1990s generation. Figure 1 shows the trend of the means of intergenerational inheritance indexes, intergenerational inflow indexes, and intergenerational outflow indexes. Moreover, the means of the intergenerational inheritance indexes decreased significantly at first and then increased slowly over time; both means of the intergenerational outflow and inflow indexes were basically declining and gradually deviated from 1, suggesting that the offspring have fewer opportunities to change their original social class, a certain social class is less likely to absorb the offspring of other social classes, and social openness is gradually declining.

Thus, from the perspective of relative mobility rates, the intergenerational mobility level in Chinese society has been gradually declining since the implementation of the reform and opening-up policy, which are in line with $\mathrm{Li}$ (2002) and $\mathrm{Li}$ (2011).

Next, the intergenerational upward and downward mobility indexes for the whole country and the four birth generations were calculated to further analyze the directional trend of the intergenerational mobility. As shown in Table 5, for the entire nation, the intergenerational upward mobility index is higher than the intergenerational downward mobility index, that is, the likelihood of the intergenerational upward mobility is relatively higher. From the perspective of each generation, both the intergenerational upward and downward mobility indexes exhibited an upward trend at first and then a downward trend; however, the intergenerational upward mobility indexes were always higher than the intergenerational downward mobility indexes. Thus, since the implementation of the reform and opening-up policy, although all social classes have more opportunities to flow upward, the trend is gradually declining. The views presented above differ from Guo (2009), who not only believed that the possibility of intergenerational upward mobility in China had been greater but also gradually increased.

\section{The Reasons for the Intergenerational Mobility in China}

The analysis of the absolute mobility rates revealed that the intergenerational mobility level of Chinese society has been quite high since the implementation of the reform and opening-up policy, primarily because of the following reasons:

First, China's economy has continued to develop rapidly since the implementation of the reform and opening-up policy. Based on the statistics of the National Bureau 


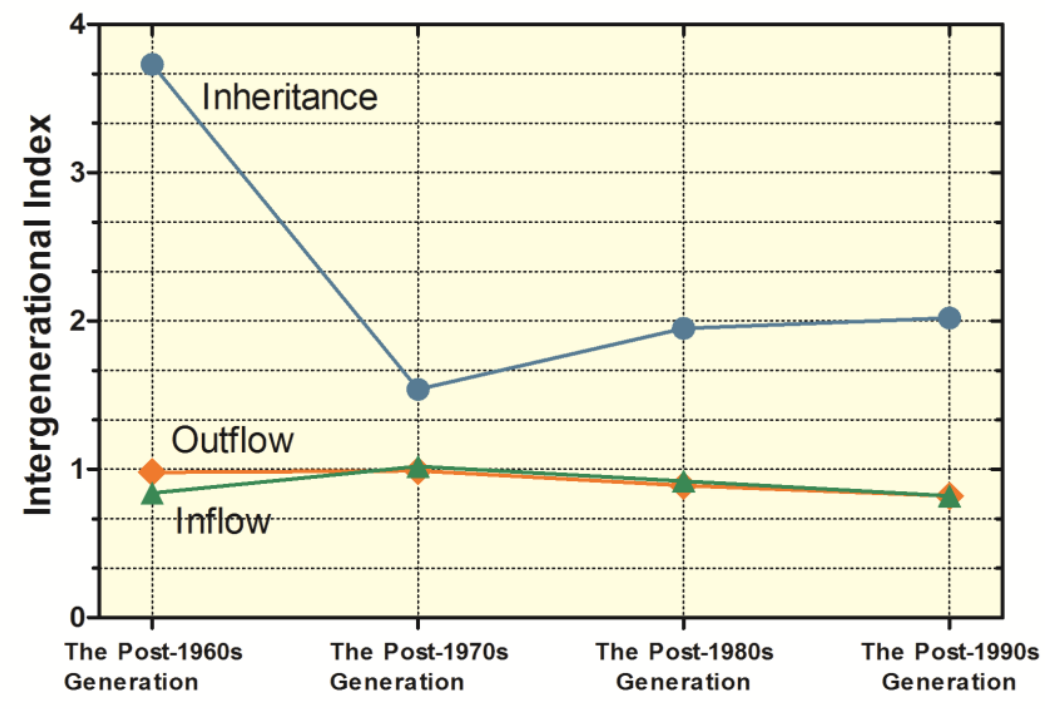

Figure 1. The Trends of Means of the Intergenerational Inheritance Indexes, the Means of the Intergenerational Outflow Indexes and the Means of the Intergenerational Inflow Indexes.

of Statistics of China, the GDP growth rates in three periods since the implementation of the reform and opening-up policy has been excellent: the average GDP growth rates was $11.5 \%$ during 1982-1988, 11.9\% during 1992-1997, and 10.1\% during 2002-2011. China's sustained and rapid economic growth has provided a solid economic foundation for the intergenerational mobility.

Second, the economic structure, especially industrial structure and career structure, was changed by technological progress. While it changed the pattern of employment positions, it also provided more new jobs and promoted the intergenerational mobility. Figures $\mathbf{2}$ and 3, respectively, show the proportion of the output value of the three major industries in GDP and the changes in the number of employees in the three major industries during 1978-2018. We found that since the implementation of the reform and opening-up policy, the proportion of the output value of China's primary industry in GDP decreased markedly, the proportion of the output value of the secondary industry in GDP decreased gradually in the fluctuation, and the proportion of the output value of the tertiary industry in GDP increased steadily increased. In such an industrial development pattern, the employee composition of the three industries also changed correspondingly. For instance, with the decline of the contribution of the primary industry to economic growth, abundant agricultural workers poured into cities and towns, who gradually were in the ranks of skilled and unskilled workers in the secondary industries, such as construction, and became "migrant workers." The steady development 


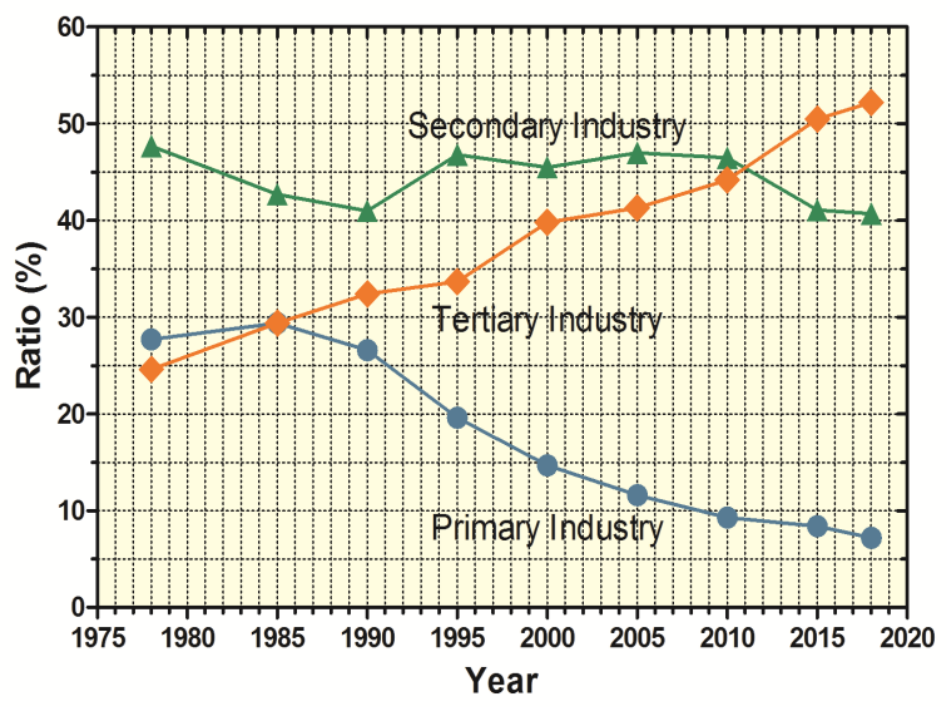

Figure 2. The Proportions of the Output Value of the Three Major Industries in China's GDP from 1978 to 2018. (Source: China Statistical Yearbook)

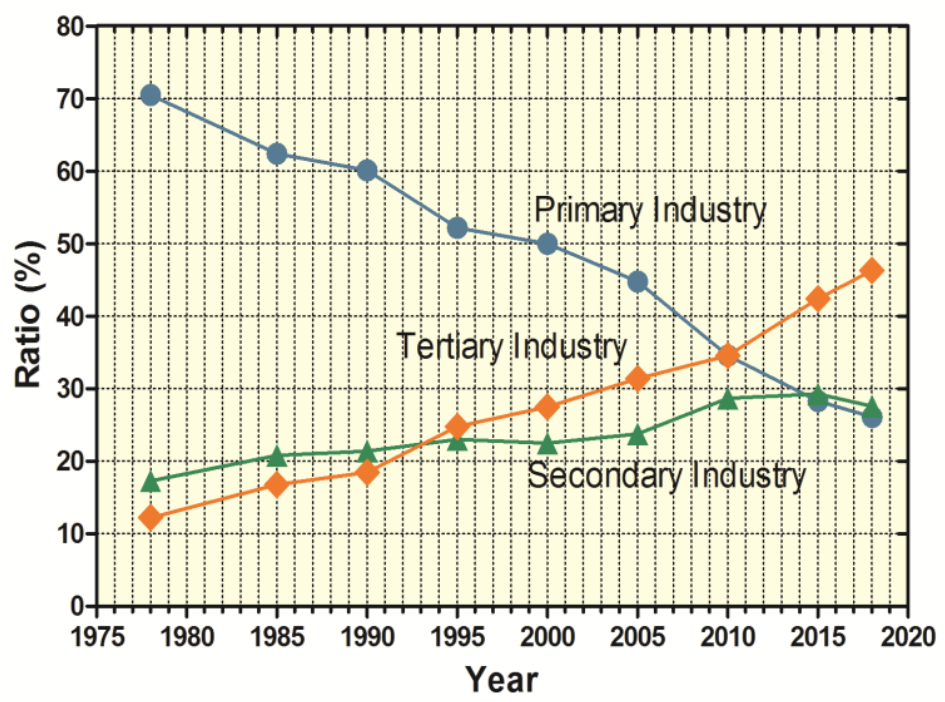

Figure 3. The Changes in the Employee Composition of the Three Major Industries in China from 1978 to 2018. (Source: China Statistical Yearbook) 
of the tertiary industry, such as commerce and service industry, led to the rapid growth of private entrepreneurs, whose flexible employment forms could absorb more people from lower classes. In addition, with the adjustment of China's industrial structure, especially the rapid development of high-tech industries and new service industries, a great deal of new occupations, such as software engineers, financial planners, online media editors, electronic game or animation designers, mushroomed rapidly, which objectively provided more jobs.

Third, in the context of rapid economic growth, China's marketization and urbanization levels continue to improve. The loosening of the household registration system and the reform of the personnel system render the labor market mechanism increasingly mature. The employment system is ever more flexible, and the channels realize that social mobility is progressively smoother. For example, many rural Chinese can realize upward mobility, although they mainly flow to social classes of lower status such as unskilled workers and skilled workers. Nevertheless, the change is rather meaningful for the offspring of agricultural workers who are in the lowest position of the whole society.

Fourth, the wave of reform and opening-up drastically changed the traditional employment system. Especially in the 1990s, numerous employees in the government or state-owned enterprises resigned; they started a business and became private entrepreneurs. In addition, China implemented the reform of state-owned enterprises in the late 1990s, resulting in the unemployment of massive employees in the original stateowned enterprises. Thus, more employees in the state-owned system moved out. Meanwhile, the process of urbanization engaged many farmers in commercial activities. Consequently, a new force in Chinese society, private proprietors, rose; this group primarily includes individual businessperson, small- and medium-sized private proprietors, and large private proprietors. Private proprietors, especially early entrants, completely enjoyed the dividends of the market economy; their income level was also relatively high. The large private proprietors are even at the top of the social class structure. The individual industrial and commercial businesspersons and small- and medium-sized private proprietors are mostly in the middle of the social class structure because of the limited authoritative resources and lower social reputation. With the reform and development of the market economy, the disadvantaged groups have more opportunities to break the barriers of the identity system and realize the intergenerational upward mobility.

Fifth, in the early 1980s, China strictly implemented the family planning policy, which advocated only one child per couple. The policy significantly affected urban residents, especially people in the state-owned system. With the implementation of the family planning policy, the number of children of urban residents, especially those from superior classes, reduced relatively, creating plenty of room for children of rural and inferior classes to realize upward mobility.

Sixth, China began resuming the college entrance examination in 1977. A considerable number of people entered universities by taking the college entrance examination, thereby becoming a group with higher identity after graduation. This group at- 
tained the intergenerational upward mobility by receiving higher education and entering the workforce after the implementation of the reform and opening-up policy; they jumped from what might have been a lower social class to a higher one.

Seventh, in the field of education, besides the policy of resuming the college entrance examination, two other events hugely affected the intergenerational mobility. In 1986, China enacted "Law on Compulsory education." In 1999, Chinese universities began implementing a large-scale enrollment expansion policy. With the popularization of compulsory education and higher education, children from lower social classes could receive the most basic national education and have more opportunities to receive higher education, which undeniably helped people from the bottom of the society to realize upward mobility.

While we have clarified the reasons for the higher level of the intergenerational mobility in the sense of absolute mobility rates, from the perspective of relative mobility rates, the intergenerational mobility level in Chinese society is relatively low, even is slowly declining. The reasons are not quite affirmative but analyzed as follows.

The lower level of the intergenerational mobility as measured by the relative mobility rates may imply that the mobility opportunities for different social classes are not equal in China. Since the implementation of the reform and opening-up policy, the inequality in Chinese society has become even more prominent. Notable differences exist in the economic capital, social capital, and cultural capital possessed by different social classes, which is further transmitted to children under the circumstance of unequal opportunities. Furthermore, intragenerational inequality is transmitted to intergenerational inequality, which further aggravates intragenerational inequality; such a cycle will make social inequality even more severe in the future.

We also analyzed the reasons for the slow decline of the intergenerational mobility in China since the implementation of the reform and opening-up policy. The majority of the post-1960s generation began receiving education during the Cultural Revolution. Affected by social unrest, the educational level of the post-1960s generation is universally low, and family backgrounds exert relatively little influence on their educational attainment. From the perspective of employment, the post-60s generation mostly started working after the Cultural Revolution and at the beginning of the implementation of the reform and opening-up policy, just at the time when children could not inherit the occupation of their parents and had to hunt jobs autonomously. Thus, family backgrounds also exerted relatively small impacts on their social status. For the post60 s generation, the impacts of family backgrounds on their education and social class status were relatively small; the influence of education to promote the intergenerational upward mobility is relatively big. Thus, differences in intergenerational mobility opportunities among social classes are relatively small and the social class structure is of high openness relatively. The post-1970s generation began receiving education after the Cultural Revolution and started working before or at the beginning of the market economic system reform; both their education and employment were markedly influenced by the era of planned economy. Although education and other induced factors play a prominent role in promoting the intergenerational upward mobility, the impact of family 
backgrounds on education attainment and social class status attainment is also increasing. Meanwhile, the inequality problem of the mobility opportunities among social classes is gradually emerging. The post-1980s generation began receiving education before or at the beginning of the reform of the market economy system and began entering the labor market during the reform of the market economy system. During the period when the "post-1990s generation" group received education, China's basic education and higher education gradually changed from expanding quantity to pursuing quality, and the educational competition among different social classes even began shifting to the field of private tutoring, causing a prominent problem of educational inequality. When the post-1990 generation entered the labor market, the economic growth slowed down gradually and the employment situation became increasingly severe, making it more challenging for them to obtain good job opportunities. Thus, although the market economy is developing rapidly, for the post-1980s and post-1990s generations, the contradiction between efficiency and fairness is increasingly prominent. Furthermore, family backgrounds have an increasing influence on education attainment and social class status attainment, and the gaps in intergenerational mobility opportunities among different social classes have further expanded.

\section{Conclusions}

Based on the CGSS in 2013 and 2015, we studied the trend of the intergenerational mobility in China since the implementation of the reform and opening-up policy by evaluating the absolute and relative mobility rates based on the mobility table. The main conclusions of this study are as follows.

First, the intergenerational mobility level measured by the absolute and relative mobility rates is not consistent. From the perspective of the absolute mobility rates, the intergenerational mobility level in Chinese society has been relatively high since the implementation of the reform and opening-up policy. No problem of solidification exists in China's social class structure and the society maintains relatively high openness. From the perspective of relative mobility rates, the intergenerational mobility level in Chinese society is relatively low and has been declining gradually since the implementation of the reform and opening-up policy. A certain degree of solidification exists in China's social class structure. Two problems worth noting are as follows. First, the intergenerational inheritance effects of all social classes in Chinese society are relatively apparent; however, under the limited intergenerational mobility level, the overall trend of the intergenerational mobility is still upward. Besides, every social class has certain opportunities to flow to other social classes, but mobility is mostly short distance flow.

Second, education is a major factor affecting the intergenerational mobility level in China. Since the implementation of the reform and opening-up policy, China's economy has been developing rapidly. In addition, China has implemented a series of major educational decisions such as the resumption of the college entrance examination, compulsory education policy, and college enrollment expansion policy. Then, the educational level of Chinese citizens has been generally promoted. However, differences in 
the educational attainment of children from different social classes are also expanding gradually, and educational inequality is increasingly prominent. Furthermore, the role of education in promoting the intergenerational upward mobility is weakened, thereby declining relative mobility rates.

Third, there are few samples of the post-1990s generation in the analysis database because of limited data. We could not comprehensively describe the trend of the intergenerational mobility in the recent and future periods. However, based on the analysis of the reasons for the intergenerational mobility during the period of implementation of the reform and opening-up policy, the conclusions mentioned above can still be drawn. From the viewpoint of the absolute mobility rates, although China's economic growth is slowing, the overall social development remains stable, which determines that the absolute mobility rates of Chinese society could maintain a high level in recent years. From the perspective of the relative mobility rates, specific differences exist in the economic capital, social capital, and cultural capital owned by different social classes, which could be difficult to change in a short period and might even be further differentiated. Thus, the relative mobility rates of Chinese society might still be low in recent years.

Fourth, the absolute mobility rates depict the efficiency of the intergenerational mobility, while the relative mobility rates denote the fairness of the intergenerational mobility. However, since the implementation of the reform and opening-up policy, Chinese society seems to present a state of insufficient equity but quite efficient. Under the condition of the market economy, fairness is inevitably subordinate to efficiency; however, once the problem of fairness intensifies, it could lead to social conflicts and eventually affect efficiency. On the one hand, the contradiction between efficiency and fairness illustrates the mobility opportunities brought by economic marketization, while it also explains the necessity of government policy to ensure equal opportunities. Currently, China's economy experiences a stage of high-quality development instead of rapid growth and is facing a challenge of avoiding the middle-income trap. Meanwhile, social inequality has become increasingly prominent. Striking a balance between fairness and efficiency is, indeed, a difficult problem in front of the Chinese government.

Overall, from the perspective of the absolute mobility rates, China's social class structure has become increasingly open since the implementation of the reform and opening-up policy. However, from the perspective of the relative mobility rates, the social class structure displays a specific phenomenon of solidification. The key to maintaining a high level of absolute mobility is to create a healthy and stable environment for economic development, while ensuring a high level of relative mobility needs effective measures to improve social inequality, of which education equality is essential. 


\section{References}

Becker, G.S., \& Tomes, N. (1979) An equilibrium theory of the distribution of income and the intergenerational mobility. Journal of Political Economy; 87(6):1153-1189.

Chen, L., \& Yuan, Z. (2012) The trend and mechanism of intergenerational income mobility in China. The Journal of World Economy, 2012(6):115-131.

Erikson, R., \& Goldthorpe, J. H. (1992) The constant flux: a study of class mobility in industrial societies. Oxford: Clarendon Press.

Ganzeboom, H.B.G., Luijkx, R., \& Treiman, D.J.(1989) International class mobility in comparative perspective. Research in Social Stratification \& Mobility, 8:3-79.

Glass, D.V., \& Berent, J. (1954) Social mobility in Britain. population (French edition); 9(4):776.

Gu, H. (2016) A study of "generation X 2" from the perspective of social mobility. Hefei: Hefei Industrial University Press.

Guo, C. (2009) Education and the intergenerational mobility. Beijing: Peking University Press.

Handlin, O., Lipset, S. M. \& Bendix, R. (1959) Social mobility in industrial society. Administrative Science Quarterly; 65(65):502-505.

Li, L. (2002) Institutional transformation and changes in stratification structurecontinued reproduction of the pattern of relative relations among social class. Social Sciences in China; (6):105-118.

Li, L., \& Zhou, G. (2014) Intergenerational transmission and social mobility in China: an analysis of income, occupation, education and political status. Zhejiang social sciences; (5):11-22.

Li, Q. (2008) Ten lectures on social stratification. Beijing: Social Sciences Academic Press.

Lu, X. (2004) Contemporary social mobility of China. Beijing: Social Sciences Academic Press.

Li, Y. (2011) Trends of status homogamy in China: a dual-trait analysis. Sociological studies; (4):122-136.

Sun, L. (2003) Fracture, Chinese society since 1990s. Beijing: Social Sciences Academic Press.

Torche, F. (2015)Analyses of the intergenerational mobility: an interdisciplinary review. Annals of the American Academy of Political \& Social Science; 657(1):3762.

Treiman, D., \& Ganzeboom, H. (2000) The fourth generation of comparative stratification research.

Quah, S.R., \& Sales A. (Year N/A) The international handbook of sociology. London: SAGE Publications Ltd: 123-150.

Xie, Y. (1992) The log-multiplicative layer effect model for comparing mobility tables. American Sociological Review;57(3):380.

Yang, J., \& Zhang, H. (2015)The changing trend of intergenerational income mobility of urban residence in China. Public Finance Research; (7):40-45. 